\title{
Kajian Penambahan Konsentrasi Susu Skim Terhadap Mutu Minuman Yogurt dari Limbah Air Cucian Beras Lokal
}

\author{
Study on the Addition of Skim Milk Concentration on the Quality of Yoghurt Drink Made of Water \\ from Rice Cleansing Water
}

Arjuman Leko*, Vita N. Lawalata, Sandriana J. Nendissa

\author{
Program Studi Teknologi Hasil Pertanian Fakultas Pertanian Universitas Pattimura \\ Jl. Ir. M. Putuhena Kampus Poka Ambon 97233 \\ Penulis Korespondensi: joemanleko94@gmail.com
}

\begin{abstract}
Water from the washing of rice during rice cooking process is considered wastewater. This rice cleansing water contains nutrients such as carbohydrates, proteins and $\mathrm{B}_{1}$ vitamin which alternatively can be used to make yogurt drink with the addition of skim milk. The purpose of this research was to obtain the exact skim milk concentration to produce the best quality of yogurt drink from rice cleansing water. A completely randomized experimental design with three levels of skim milk concentrations i.e.: 5 , 10, and $15 \%$ with three replications were applied in this research. Observed variables include total acid, protein, fat, and total bacteria content, as well as an organoleptic test (viscosity, consistency, flavor, and taste). The 10\% skim milk concentration was found to be the best treatment resulting in yogurt drink with total acid, protein, fat, total bacteria content of $1.11 \%, 3.54 \%, 1.55 \%$, and $1.50 \mathrm{CFU} / \mathrm{mL}$ respectively, viscosity and taste of the organoleptic of the drink were 3.15 and 3.25 subsequently.
\end{abstract}

Keywords: rice cleansing water, skim milk, yogurt drink

\begin{abstract}
ABSTRAK
Air cucian beras merupakan limbah dari proses pengolahan beras menjadi nasi. Air cucian beras mengandung zat gizi berupa karbohidrat, protein dan vitamin $\mathrm{B}_{1}$ yang secara alternatif dapat dimanfaatkan untuk pembuatan minuman yogurt dengan penambahan susu skim. Tujuan dari penelitian ini adalah untuk memperoleh konsentrasi susu skim yang tepat untuk menghasilkan mutu terbaik pada minuman yogurt dari limbah air cucian beras. Penelitian ini menggunakan rancangan acak lengkap dengan tiga kali ulangan dan konsentrasi susu skim yang berbeda yaitu: 5, 10, dan 15\%. Peubah-peubah yang diamati meliputi total asam, kadar protein, kadar lemak, dan total bakteri, serta uji organoleptik (kekentalan, konsistensi, aroma dan rasa). Perlakuan terbaik pada penelitian ini yaitu penambahan konsentrasi susu skim dengan konsentrasi $10 \%$ dengan total asam $1,11 \%$, kadar protein 3,54\%, kadar lemak 1,55\%, dan total bakteri $1,50 \mathrm{cfu} / \mathrm{mL}$, kemudian kekentalan dan rasa pada uji organoleptik minuman yogurt adalah 3,15 dan 3,25.
\end{abstract}

Kata kunci: air cucian beras, minuman yogurt, susu skim

\section{PENDAHULUAN}

Minuman yogurt adalah salah satu minuman yang terbuat dari susu segar yang difermentasi oleh bakteri asam laktat. Bakteri ini memiliki efek menguntungkan bila dikonsumsi dengan cara memperbaiki mikroflora saluran pencernaan (Fuller, 1992).

Proses pembuatan minuman yogurt biasanya menggunakan susu segar yaitu susu sapi maupun 
susu kambing sebagai bahan utama. Bahan lain selain susu segar yang dapat digunakan untuk pembuatan minuman yogurt adalah kedelai, beras merah, kacang merah, ubi jalar ungu, jagung, dan anggur. Fungsi dari penggunaan bahan lain selain susu segar dalam pembuatan minuman yogurt adalah sebagai alternatif untuk menggantikan susu segar yang agak sulit diperoleh, memberikan manfaat fungsional bagi kesehatan, dan mengoptimalkan pemanfaatan dari bahan pangan yang diolah menjadi minuman yogurt (Sintasari et al., 2014; Tari et al., 2016; Wardhani et al., 2015). Salah satu bahan yang dapat digunakan untuk pembuatan minuman yogurt adalah limbah air cucian beras yang proses pembuatannya sama dengan proses pembuatan minuman yogurt dari susu segar.

Penelitian terdahulu menunjukkan bahwa beras merah digunakan untuk pembuatan minuman yogurt (Sintasari et al., 2014). Selain beras merah, beras putih juga diduga dapat digunakan sebagai bahan baku pembuatan minuman yogurt karena kandungan karbohidrat dan protein yang cukup tinggi.

Pada proses pengolahan ini beras biasanya dicuci berulang kali. Air cucian beras biasanya dibuang karena dianggap tidak bermanfaat, namun sebenarnya air cucian beras masih mengandung nilai gizi. Air cucian beras mengandung karbohidrat $85 \%$, protein $8 \%$ serta vitamin $\mathrm{B}_{1} 80 \%$ (Haryadi, 2006). Limbah air cucian beras berpotensi digunakan untuk pembuatan minuman yogurt, hal ini didasari pemikiran bahwa limbah air cucian beras ini memenuhi syarat untuk pertumbuhan bakteri karena terdapat kandungan karbohidrat yang cukup memadai. Kekurangan dari air cucian beras yaitu tidak terdapatnya kandungan laktosa yang merupakan nutrisi utama bagi pertumbuhan bakteri asam laktat selama proses fermentasi minuman yogurt, sehingga perlu ditambahkan susu skim.

Susu skim merupakan sumber energi dan metabolisme terhadap pertumbuhan bakteri asam laktat dalam pembuatan minuman yogurt karena mengandungan laktosa yang cukup tinggi. Susu skim dapat mempertahankan konsistensi minuman yogurt dan berpengaruh terhadap tingkat penerimaan masyarakat yang berkaitan dengan aroma yang dihasilkan, serta penggunaan susu skim dapat mengurangi rasa langu dari air cucian beras (Helferich \& Westhoff, 1980). Penelitian sebelumnya mendapatkan bahwa penggunaan susu skim $7 \%$ dan $3 \%$ tepung kedelai menghasilkan minuman yogurt dengan kualitas yang baik (Setioningsih et al., 2004). Penelitian yang lain yaitu susu skim 9\% dan sukrosa 7\% merupakan perlakuan terbaik pada minuman yogurt sari beras merah (Sintasari et al., 2014), serta penggunaan susu skim 5\% menghasilkan minuman yogurt dengan karakteristik mutu yang baik pada minuman yogurt jagung manis (Wardhani et al., 2015).

Berdasarkan latar belakang diatas, penulis tertarik untuk melakukan penelitian dengan judul kajian penambahan konsentrasi susu skim terhadap mutu minuman yogurt dari limbah air cucian beras lokal. Penelitian ini bertujuan untuk menganalisa mutu minuman yogurt dari limbah air cucian beras dengan penambahan konsentrasi susu skim 5, 10, dan $15 \%$.

\section{BAHAN DAN METODE}

\section{Bahan}

Bahan utama yang digunakan dalam penelitian ini antara lain: beras putih varietas Cigelis sebanyak $9 \mathrm{~kg}$ (diperoleh dari Desa Unit, Kabupaten Buru, Provinsi Maluku), gula pasir (merek Gulaku), susu bubuk skim (Tropicana Slim), starter yogurt (Biokul Natural Set Yoghurt yang mengandung bakteri Bifidobacterium, $L$. acidophilus, L. bulgaricus dan S. thermophilus) dan air bersih. Bahan kimia yang digunakan untuk preparasi sampel dan analisis berasal dari Merck, meliputi indikator fenolftalin, $\mathrm{NaOH}, \mathrm{K}_{2} \mathrm{SO}_{4}, \mathrm{HgO}$, $\mathrm{H}_{2} \mathrm{SO}_{4}, \mathrm{H}_{3} \mathrm{BO}_{3}, \mathrm{HCl}$, petroleum eter, dan Plate Count Agar.

\section{Desain Penelitian}

Penelitian ini di desain menggunakan rancangan acak lengkap faktor tunggal dengan tiga kali ulangan. Sebagai perlakuan yaitu tingkat pengaruh konsentrasi susu skim yang terdiri dari 3 taraf perlakuan, yaitu: susu skim 5\%,10\%, dan $15 \%$ dari volume air cucian beras.

\section{Persiapan Sampel}

Beras sebanyak $3 \mathrm{~kg}$ disortasi untuk memisahkan butir-butir beras dari bekatul beras dan kontaminan lainnya, kemudian dicuci sebanyak dua kali, masing-masing pencucian 
dengan $4500 \mathrm{~mL}$ air. Air cucian beras tersebut kemudian disaring dan didiamkan selama 1 jam sampai terbentuk endapan dibagian bawah air cucian tersebut. Air endapan diambil sebanyak $1800 \mathrm{~mL}$ dengan cara pisahkan lapisan air bagian atas yang berwarna agak bening dari endapan yang terbetuk dan ditampung dalam wadah.

\section{Pembuatan Minuman Yogurt dari Limbah Air Cucian Beras}

Air endapan cucian beras dipanaskan menggunakan kompor listrik sampai mencapai suhu $100^{\circ} \mathrm{C}$ selama 30 menit, kemudian ditambahkan gula pasir sebanyak $8 \%$ dan susu bubuk skim dengan konsentrasi sesuai perlakuan $(5 \%, 10 \%$ dan $15 \%)$ dan diaduk-aduk. Hasil campuran ini dituangkan kedalam wadah yang sudah disterilisasi dan didinginkan hingga suhu $43^{\circ} \mathrm{C}$, kemudian ditambahkan starter yogurt sebanyak $35 \%$, selanjutnya diinkubasi dalam oven inkubator bertemperatur $43^{\circ} \mathrm{C}$ selama $24 \mathrm{jam}$, dan hasil akhirnya berupa minuman yogurt.

\section{Variabel Pengamatan}

Variabel pengamatan yang diamati meliputi: uji total asam, kadar protein, kadar lemak, total bakteri, dan uji organoleptik perbandingan jamak.

\section{Analisis Data}

Data yang terkumpul selanjutnya dianalisis menggunakan analisis ragam yang sesuai dengan rancangan yang digunakan. Jika terdapat perlakuan yang berbeda nyata, maka akan dilanjutkan dengan uji beda nyata jujur (BNJ) pada taraf $95 \%$.

\section{HASIL DAN PEMBAHASAN}

\section{Total Asam}

Minuman yogurt dari limbah air cucian beras dengan perlakuan susu skim pada konsentrasi 5\% mempunyai total asam sebesar $0,93 \%$ dan terus mengalami peningkatan pada konsentrasi $10 \%$ sebesar $1,11 \%$ dan konsentrasi $15 \%$ sebesar $1,41 \%$ (Tabel 1 ).

Selama fermentasi bakteri asam laktat melakukan proses metabolisme yang menghasilkan asam laktat yang terukur sebagai total asam. Nilai total asam cenderung meningkat seiring dengan meningkatnya konsentrasi susu skim yang ditambahkan. Hal ini disebabkan karena semakin banyak nutrisi yang tersedia maka akan mempengaruhi pertumbuhan bakteri asam laktat, karena selama fermentasi bakteri asam laktat mampu memecah laktosa pada susu skim maupun gula lainnya seperti glukosa, galaktosa, fruktosa, sukrosa dan maltosa menjadi asam laktat.

Menurut Indira (2007), susu skim mengandung laktosa yang cukup tinggi yang akan diubah sebagian besar oleh bakteri asam laktat menjadi asam laktat. Laktosa merupakan sumber energi dan karbon bagi starter bakteri asam laktat, sehingga semakin banyak susu skim yang ditambahkan maka jumlah bakteri asam laktat akan semakin meningkat. Penelitian ini sesuai dengan hasil penelitian dari Sintasari et al. (2014), bahwa penambahan susu skim pada minuman probiotik sari beras merah mampu meningkatkan kadar asam laktat yang terukur sebagai total asam. Menurut Badan Standarisasi Nasional (2009), total asam laktat pada minuman yogurt sebesar 0,5-2,0\%, dengan demikian total asam laktat pada penelitian ini yaitu untuk semua perlakuan masih memenuhi standar.

\section{Kadar Protein}

Minuman yogurt dari limbah air cucian beras dengan perlakuan susu skim pada konsentrasi 5\% mempunyai kadar protein sebesar $3,01 \%$ dan terus mengalami peningkatan pada konsentrasi $10 \%$ sebesar 3,54\% dan perlakuan $15 \%$ sebesar 4,02\% (Tabel 1).

Kadar protein terus meningkat seiring dengan meningkatnya konsentrasi susu skim yang ditambahkan. Hal ini terjadi karena protein yang terdapat pada susu skim akan dirombak menjadi asam-asam amino dengan adanya degradasi protein oleh enzim-enzim protease yang berasal dari bakteri asam laktat. Dugaan ini diperkuat oleh Granito dan Àlvarez (2006), bahwa protein pada susu skim yang didegradasi oleh enzim protease dan peptidase akan menyebabkan pelepasan asam amino dan rantai pendek peptida. Yusmarini dan Efendi (2004) juga menjelaskan bahwa komponen utama penyusun sel bakteri asam laktat adalah protein, sehingga semakin banyak sel yang lisis maka semakin tinggi kadar protein pada minuman yogurt. 
Tabel 1. Hasil uji kimia, mikrobiologi dan organoleptik minuman yogurt dari limbah air cucian beras.

\begin{tabular}{ccccccc}
\hline Perlakuan & $\begin{array}{c}\text { Total asam } \\
(\%)\end{array}$ & $\begin{array}{c}\text { Protein } \\
(\%)\end{array}$ & $\begin{array}{c}\text { Lemak } \\
(\%)\end{array}$ & $\begin{array}{c}\text { Total bakteri } \\
(\mathrm{cfu} / \mathrm{mL})\end{array}$ & Kekentalan & Rasa \\
\hline Konsentrasi susu skim 5\% & $0,93 \mathrm{a}$ & $3,01 \mathrm{a}$ & $1,52 \mathrm{a}$ & $3,3 \mathrm{a}$ & $2,80 \mathrm{a}$ & $2,90 \mathrm{a}$ \\
Konsentrasi susu skim 10\% & $1,11 \mathrm{ab}$ & $3,54 \mathrm{~b}$ & $1,55 \mathrm{~b}$ & $1,5 \mathrm{~b}$ & $3,15 \mathrm{ab}$ & $3,25 \mathrm{ab}$ \\
Konsentrasi susu skim 15\% & $1,41 \mathrm{~b}$ & $4,02 \mathrm{c}$ & $1,58 \mathrm{c}$ & $0 \mathrm{c}$ & $3,50 \mathrm{~b}$ & $3,60 \mathrm{~b}$ \\
\hline
\end{tabular}

Keterangan: Angka yang diikuti huruf yang sama menyatakan tidak berbeda nyata pada uji BNJ $\alpha=0,05$

Menurut Cannadian Dairy Commision (2011), susu skim bubuk memiliki kandungan protein sekitar $34-37 \%$. Tingginya protein pada susu skim dapat menjelaskan bahwa semakin tinggi susu skim yang ditambahkan pada variasi produk, maka kandungan protein juga akan semakin meningkat. Penelitian ini sesuai dengan hasil dari penelitian Fadro et al. (2015), bahwa penambahan susu skim dapat meningkatkan kadar protein pada minuman probiotik susu jagung. Menurut Badan Standarisasi Nasional (2009), kadar protein yang terdapat pada minuman yogurt minimal 3,50\%, dengan demikian kadar protein pada penelitian ini yaitu konsentrasi $(10 \%)$ dan (15\%) masih memenuhi standar.

\section{Kadar Lemak}

Minuman yogurt dari limbah air cucian beras dengan perlakuan susu skim pada konsentrasi 5\% mempunyai kadar lemak sebesar $1,52 \%$ dan terus mengalami peningkatan pada konsentrasi $10 \%$ sebesar $1,55 \%$ dan konsentrasi $15 \%$ sebesar $1,58 \%$ (Tabel 1 ).

Peningkatan kadar lemak terjadi seiring dengan meningkatnya konsentrasi susu skim yang ditambahkan. Meningkatnya kadar lemak disebabkan karena adanya perubahan sebagian karbohidrat menjadi lemak. Amilosa dalam pati akan diubah menjadi maltosa dan sedikit glukosa. Sisa glukosa yang berlebihan dalam jumlah kecil kemudian akan diubah menjadi lemak. Selain itu, bakteri fermentasi memiliki sifat pereduksi yang kuat, dimana dalam kondisi fermentasi aktif media yang mengandung gula akan terjadi reduksi aldehid menjadi alkohol dan salah satunya terbentuk gliserol sehingga akan mempengaruhi peningkatan kadar lemak (Ambardini, 2007). Selain itu, kadar lemak pada minuman yogurt juga dipengaruhi oleh kondisi starter yogurt, perkembangan bakteri yogurt dan kadar lemak awal (kadar lemak awal pada susu bubuk skim yang digunakan dalam penelitian ini sebesar 1\%).
Menurut U.S. Dairy Export Council (2005), diketahui bahwa kandungan lemak pada susu bubuk skim sebesar 0,60-1,25\%, sehingga semakin besar kandungan lemak awal pada medium minuman yogurt maka semakin besar pula kadar lemak yang akan dihasilkan (Sunarlim et al., 2007). Penelitian ini sesuai dengan penelitian dari Wijayanti et al. (2016), bahwa penambahan susu skim dapat meningkatkan kadar lemak pada minuman yogurt sari beras hitam. Menurut Badan Standarisasi Nasional (2009), kadar lemak yang terdapat pada minuman yogurt maksimal $3,80 \%$, minuman yogurt rendah lemak sebesar $0,5-2,0 \%$, dan minuman yogurt tanpa lemak kandungan lemaknya kurang dari $0,5 \%$, dengan demikian minuman yogurt pada penelitian ini termasuk berlemak rendah (low fat).

\section{Total Bakteri}

Bakteri yang terkandung didalam minuman yogurt pada umumnya adalah bakteri probiotik berupa bakteri asam laktat, selain bakteri asam laktat terdapat juga beberapa bakteri patogen yang sering mengkontaminasi minuman yogurt. Bakteri patogen yang sering mengkontaminasi minuman yogurt adalah bakteri Coliform, E. coli, dan Salmonella.

Minuman yogurt dari limbah air cucian beras dengan perlakuan susu skim pada konsentrasi $5 \%$ mempunyai total bakteri sebesar $3,30 \mathrm{cfu} / \mathrm{mL}$ dan terus mengalami penurunan pada konsentrasi $10 \%$ sebesar $1,50 \mathrm{cfu} / \mathrm{mL}$ dan konsentrasi 15\% sebesar $0 \mathrm{cfu} / \mathrm{mL}$ (Tabel 1).

Total bakteri terus mengalami penurunan seiring dengan meningkatnya konsentrasi susu skim yang ditambahkan. Penurunan total bakteri disebabkan karena bakteri asam laktat yang terkandung pada minuman yogurt berpotensi menekan pertumbuhan bakteri patogen. Penurunan total bakteri juga disebabkan karena pembuatan minuman yogurt dari limbah air cucian beras melewati tahap sterilisasi. Menurut Widodo 
(2003), bakteri tidak dapat tumbuh pada minuman yogurt jika dalam proses pembuatannya melewati tahap sterilisasi dan bakteri asam laktat pada minuman yogurt menghasilkan metabolit sekunder berupa bakteriosin yang dapat menghambat pertumbuhan bakteri patogen yang tidak diinginkan. Penelitian terdahulu juga membuktikan bahwa secara in vitro bakteri asam laktat dari galur Lactobacillus dan Bifidobacteria dapat menghambat penempelan dan invasi bakteri enteropatogen penyebab diare (Bourlioux et al., 2003).

Menurut Indira (2007), Susu skim mengandung laktosa yang cukup tinggi. Laktosa merupakan nutrisi utama yang dapat memicu pertumbuhan bakteri asam laktat sehingga semakin tinggi konsentrasi susu skim yang ditambahkan maka pertumbuhan bakteri asam laktat akan semakin meningkat. Pertumbuhan bakteri asam laktat yang semakin meningkat akan menekan pertumbuhan bakteri patogen. Hal ini sesuai dengan penelitian dari Tari et al. (2016), bahwa bakteri asam laktat yang disuplementasikan pada yogurt dengan penambahan ekstrak ubi jalar ungu dapat menurunkan diare yang disebabkan oleh bakteri patogen. Menurut Badan Standarisasi Nasional (2009), total bakteri yang terdapat pada minuman yogurt maksimal $10 \mathrm{cfu} / \mathrm{mL}$, dengan demikian total bakteri pada penelitian ini yaitu untuk semua perlakuan masih memenuhi standar.

\section{Uji Organoleptik}

Uji organoleptik yang digunakan pada penelitian ini yaitu uji perbandingan jamak. Uji perbandingan jamak merupakan salah satu dari uji organoleptik yang digunakan untuk mengetahui apakah ada perbedaan diantara satu atau lebih contoh dengan contoh baku (kontrol) dan untuk memperkirakan besarnya perbedaan yang ada (Setyaningsih et al., 2010). Contoh baku yang digunakan pada penelitian ini di tandai dengan kode R. Atribut-atribut sensori yang diuji pada penelitian ini adalah kekentalan, konsistensi, aroma dan rasa.

\section{Kekentalan}

Tingkat penilaian panelis terhadap kekentalan pada minuman yogurt dari limbah air cucian beras dengan perlakuan susu skim pada konsentrasi (5\%) sebesar 2,80 (sama kental dengan
R), konsentrasi (10\%) sebesar 3,15 (sama kental dengan R) dan konsentrasi (15\%) sebesar 3,50 (agak sama kental dengan R).

Peningkatan kekentalan terjadi seiring dengan meningkatnya konsentrasi susu skim yang ditambahkan. Meningkatnya kekentalan disebabkan karena penambahan susu skim dapat meningkatkan kadar protein yang akan mengalami koagulasi membentuk gel karena adanya asam laktat pada minuman yogurt. Dugaan ini diperkuat oleh Wahyudi dan Samsundari (2008), bahwa terbentuknya asam laktat selama proses pembuatan minuman yogurt menyebabkan peningkatan total asam dan koagulasi protein pembentuk gel. Menurut Triyono (2010), bahwa semakin tinggi kadar protein dalam minuman yogurt maka kekentalan minuman yogurt akan semakin tinggi. Protein yang terkoagulasi oleh asam akan membentuk gel sehingga tekstur minuman yogurt menjadi lebih kental.

Sintasari et al. (2014), menyatakan bahwa peningkatan susu skim akan meningkatkan kekentalan pada minuman yogurt, sebab selama proses fermentasi laktosa akan diubah menjadi asam laktat yang bersifat asam sehingga menyebabkan terjadinya koagulasi protein susu yang menyebabkan minuman yogurt menjadi kental. Penelitian ini sesuai dengan penelitian dari Wardhani et al. (2015), bahwa penambahan susu skim akan meningkatkan kekentalan pada minuman yogurt jagung manis.

\section{Konsistensi}

Konsistensi pada minuman yogurt dapat diamati dari menyatu atau tidaknya campuran bahan padatan terlarut serta keseragamannya yang terbentuk dalam minuman yogurt. Selain itu kadar protein, pembentukan koagulan atau gel dan tingkat kekentalan yang dihasilkan juga mempengaruhi tingkat konsistensi pada minuman yogurt (Triyono, 2010). Konsistensi yang baik ditandai dengan kenampakan yang seragam dan homogen pada minuman yogurt (SNI, 2009).

Konsistensi yang dihasilkan oleh minuman yogurt dari limbah air cucian beras pada penelitian ini yaitu untuk semua perlakuan tidak berbeda dengan konsistensi pada minuman yogurt komersial (R) yang digunakan sebagai pembanding. Hal ini dapat terjadi karena minuman yogurt dari limbah air cucian beras untuk semua perlakuan menghasilkan tingkat konsistensi yang 
relatif sama dengan konsistensi yang terdapat pada minuman yogurt komersial (R), sehingga panelis sulit membedakan tingkat konsistensi pada sampel perlakuan dengan sampel baku (R) yang digunakan.

\section{Aroma}

Hasil analisis ragam dalam ketentuan uji perbandingan jamak apabila memberikan pengaruh yang tidak nyata, maka dapat diindikasikan bahwa sampel dengan perlakuan yang digunakan tidak memberikan perbedaan yang nyata dengan sampel baku (R) sehingga perlakuan tidak menghasilkan perbedaan yang dapat dideteksi (Setyaningsih et al., 2010). Dengan demikian dapat disimpulkan bahwa aroma yang dihasilkan oleh minuman yogurt dari limbah air cucian beras pada penelitian ini yaitu untuk semua perlakuan tidak berbeda dengan aroma pada minuman yogurt komersial (R) yang digunakan sebagai pembanding. Hal ini dapat terjadi karena minuman yogurt dari limbah air cucian beras pada semua perlakuan menghasilkan aroma yang cenderung sama dengan aroma pada minuman yogurt komersial (R), sehingga panelis sulit membedakan aroma pada sampel perlakuan dan sampel baku (R) dengan lebih spesifik.

\section{Rasa}

Minuman yogurt memilik rasa asam yang khas. Rasa yang dihasilkan oleh minuman yogurt terbentuk karena aktivitas bakteri asam laktat dari galur Streptococcus thermophilus selama proses fermentasi sehingga menimbulkan citarasa asam yang khas pada minuman yogurt. Bakteri asam laktat dari galur Lactobacillus bulgaricus lebih berperan pada pembentukan aroma, sedangkan galur $S$. thermophilus lebih berperan dalam pembentukan citarasa pada minuman yogurt (Irkin dan Eren, 2008).

Tingkat penilaian panelis terhadap rasa pada minuman yogurt dari limbah air cucian beras dengan perlakuan susu skim pada konsentrasi (5\%) sebesar 2,90 (sama asam dengan R), konsentrasi (10\%) sebesar 3,25 (sama asam dengan $\mathrm{R}$ ) dan konsentrasi (15\%) sebesar 3,60 (agak asam dari R).

Rasa asam pada minuman yogurt semakin meningkat seiring dengan meningkatnya konsentrasi susu skim yang ditambahkan. Peningkatan rasa asam disebabkan karena selama proses fermentasi bakteri asam laktat akan menghasilkan asam laktat yang dapat meningkatkan keasasaman pada minuman yogurt. Proses fermentasi akan terjadi hidrolisis enzimatis laktosa yang selanjutnya akan diuraikan melalui beberapa tahap dekomposisi untuk menghasilkan asam laktat, asam laktat yang terbentuk akan menghasilkan keasaman yang ditandai dengan terjadinya penurunan $\mathrm{pH}$, dan pada tahap inilah dihasilkan asetaldehid yang merupakan senyawa pembentuk citarasa khas pada minuman yogurt. Hasil metabolisme laktosa berupa asam-asam organik akan mempengaruhi citarasa yang dapat menentukan kualitas minuman yogurt (Chandan, 2006).

Menurut Widodo (2003), kandungan protein yang terdapat pada susu skim juga memberikan pengaruh terhadap pembentukan rasa asam pada minuman yogurt. Bakteri asam laktat dari galur $S$. thermophilus yang berperan dalam pembentukan citarasa pada minuman yogurt dapat tumbuh dan menghasilkan asam laktat karena distimulir oleh adanya asam amino berupa lisin dan histidin dari hasil degradasi protein yang berasal dari susu skim. Susu skim juga dapat memberikan nutrisi pada bakteri asam laktat secara optimal agar bakteri asam laktat dapat menghasilkan aroma dan rasa asam yang khas akibat pembentukan asam laktat dan asam-asam organik lain sebagai hasil dari metabolitnya, dengan demikian secara tidak langsung penambahan susu skim juga dapat meningkatkan rasa asam pada minuman yogurt. Penelitian ini sesuai dengan penelitian dari Sintasari et al. (2014), bahwa penambahan susu skim dapat memberikan pengaruh rasa asam pada minuman probiotik sari beras merah.

\section{KESIMPULAN}

Hasil organoleptik pada minuman yogurt dari limbah air cucian beras yang sama baik dengan minuman yogurt komersial terdapat pada perlakuan dengan konsentrasi susu skim 10\% dengan tingkat kekentalan 3,15 dan rasa 3,25. Perlakuan terbaik yang terdapat pada penelitian ini yaitu perlakuan dengan konsentrasi susu skim 10\% dengan nilai total asam $1,11 \%$, kadar protein $3,54 \%$, kadar lemak $1,55 \%$, dan total bakteri 1,50 $\mathrm{cfu} / \mathrm{mL}$. 


\section{DAFTAR PUSTAKA}

Ambardini. S. 2007. Perubahan Kadar Lemak Biji Kakao (Theobroma cacao L.) Melalui Fermentasi Beberapa Isolat Khamir [Skripsi]. Universitas Haluoleo. Kendari.

Badan Standardisasi Nasional. 2009. Yogurt. SNI 01-2981-2009. Badan Standardisasi Nasional, Jakarta.

Bourlioux, P., B. Koletzko., F. Guarner, and V. Braesco. 2003. The Intestine and its microflora are partners for the protection of the host: Report on the Danone symposium 'the intelligent intestine'. Held in Paris. Am $J$ Clin Nutr 78: 410-414. DOI: 10.1093/ajen/78.4.675.

Cannadian Dairy Commision. 2011. Skim milk powder. http://www.milkingredients.ca/indexeng.php?id=192 [03 September 2017].

Chandan, R.C. 2006. Manufacturing Yogurt and Fermented Milks. Blackwell Publishing Ltd, United Kingdom: Oxford University.

Fadro, R., Efendi, dan F. Restuhadi. 2015. Pengaruh penambahan susu skim dalam pembuatan minuman probiotik susu jagung (Zea mays L.) menggunakan kultur Lactobacillus acidophilus. Jurnal Sagu 14: 28-36.

Fuller, R. 1992. Probiotics: The Scientific Basis. Springer Netherlands. DOI: 10.1007/978-94011-2364-8

Granito, M. and G. Àlvarez. 2006. Lactic acid fermentation of black beans (Phaseolus vulgaris): Microbiological and chemical characterization. Journal of the Science of Food and Agriculture 86: 1164-1171.

Haryadi. 2006. Teknologi Pengolahan Beras. Penerbit UGM Press, Yogyakarta.

Indira, R. 2007. Formulasi Minuman Probiotik Berbasis Bekatul dengan Isolat Lactobacillus plantarum B2 [Skripsi]. Fakultas Teknologi Pertanian, Universitas Brawijaya. Malang.

Irkin, R. and U.V. Eren. 2008. Research about viable Lactobacillus bulgaricus and Streptococcus thermophilus number and food science in the market yoghurt. World Journal of Dairy 3: 25-28.

Setyaningsih, D., A. Apriyantono, dan M.P. Sari. 2010. Analisis Sensori untuk Industri Pangan dan Agro. Institut Pertanian Bogor Press, Bogor.

Sintasari, R.A., J. Kusnaidi, dan D.W. Ningtyas.
2014. Pengaruh penambahan konsentrasi susu skim dan sukrosa terhadap karekteristik minuman probiotik sari beras merah. Jurnal Pangan dan Agroindustri 2: 65-75.

Standar Nasional Indonesia (SNI). 2009. SNI 2981:2009. Yogurt. Badan Standardisasi Nasional (BSN), Jakarta.

Sunarlim, R., H. Setiyanto, dan M. Poeloengan. 2007. Pengaruh kombinasi starter bakteri $L$. bulgaricus, $S$. thermophilus dan $L$. plantarum terhadap sifat mutu susu fermentasi. Prosiding Seminar Nasional Teknologi Peternakan dan Veteriner. Puslitbangnak, Bogor. pp. 270-278.

Tari, A.I.N., C.B. Handayani, dan Sudarmi. 2016. Potensi probiotik indigenus Lactobacillus plantarum Dad 13 pada yoghurt dengan suplementasi ekstrak ubi jalar ungu untuk penurunan diare dan radikal bebas. Agritech 36: 7-14. DOI: 10.22146/agritech.10677.

Triyono, A. 2010. Mempelajari Pengaruh Maltodekstrin dan Susu Skim Terhadap Karakteristik Yoghurt Kacang Hijau (Phaseolus radiatus L.). Balai Besar Pengembangan Teknologi Tepat Guna. Seminar Rekayasa Kimia dan Proses. Teknik Kimia, Universitas Diponegoro, Semarang.

U.S. Dairy Export Council (USDEC). 2005. Reference Manual for U.S. Milk Powder. Revised Edition. New York, USA.

Wahyudi, A. dan S. Samsundari. 2008. Bugar dengan Susu Fermentasi. Universitas Muhamadiyah Malang Press, Malang.

Wardhani, D.H., D.C. Maharani, dan E.A. Prasetyo. 2015. Kajian pengaruh cara pembuatan susu jagung, rasio dan waktu fermentasi terhadap karakteristik yoghurt jagung manis. Jurnal Momentum 11: 7-12.

Widodo, W. 2003. Bioteknologi Industri Susu. Lacticia Press, Yogyakarta.

Wijayanti, M.I. 2016. Kualitas Yogurt Sinbiotik Sari Beras Hitam (Oryza sativa L.) dengan Variasi Susu Skim [Skripsi]. Fakultas Teknobiologi, Universitas Atmajaya. Yogyakarta.

Yusmarini, R.E. 2004. Evaluasi mutu soyghurt yang dibuat dengan penambahan beberapa jenis gula. Jurnal Natur Indonesia 6: 104110. 